\title{
Ionotropic Glutamate Receptors (iGluRs): Overview of iGluR2 ligand binding domain in complex with agonists and antagonists
}

\author{
Zorica Serafimoska $^{1 *}$, Tommy N. Johansen ${ }^{2}$, Karla Frydenvang ${ }^{2}$, Ljubica Suturkova ${ }^{1}$ \\ ${ }^{1}$ Institute for Pharmaceutical chemistry, Faculty of Pharmacy, "St Cyril and Methodius" University Skopje, Macedonia \\ ${ }^{2}$ Department of Madical chemistry, Faculty of Pharmaceutical Sciences, University Copenhagen, Denmark
}

Received: October 2011; Accepted: November 2011

\begin{abstract}
Ionotropic glutamate receptors (iGluRs) constitute a family of ligand gated ion channels subdivided in three classes, NMDA, AMPA (iGluA1-4) and KA (1-5) according to the agonists that selectively activate them. iGluRs are tetrameric assemblies of highly homologous receptor subunits. They are critically important for normal brain function and are considered to be involved on neurological disorders and degenerative diseases such as schizophrenia, Alzheimer's disease, brain damage following stroke and epilepsy. Since the first publication of the structure of recombinant soluble protein of ligand binding domain of GluA2 extensive studies on this group of receptors were performed and many crystal structures as complexes of GluA2-LBD with agonists, partial agonists and antagonists were obtained. The structural information in combination with functional data makes good platform for consecutive investigation and design of new selective drugs which will be used in treatment of neurodegerative diseases.
\end{abstract}

Key words: Ionotropic glutamate receptors (iGluRs), AMPA(iGluA1-4), neurological disorders, degenerative diseases schizophrenia, Alzheimer's disease, epilepsy.

\section{Introduction Background}

Synapses are specialized contact site of two neurons and are important for transfer of a signal from one neuron to another. Synaptic transmission is chemical and is mediated by neurotransmitter compounds. As it is presented in the Fig. 1, neurotransmitters are released by presynaptic cell into synaptic cleft and bound by the receptor on the postsynaptic cell.In the resting position, when the agonist is not bound to the ligand binding domain (LBD), the ionchannel is closed. When the agonist is bound to the LBD, the ion channel is opening. The third form of the receptor is desensitized form when the agonist is still present in the LBD, but the ion-channel is closed by different mechanism than deactivation as described latter in this review.

(S)-Glutamic acid (Glu) is one of the most abounded excitatory neurotransmitter in the central nervous system (CNS) and has been implicated in a number of neurological

\footnotetext{
* zose@fff.ukim.edu.mk
}

and psychiatric diseases. Glu activates two different types of receptors: ionotropic (iGluRs) and metabotropic glutamate receptors (mGluRs) (Nakanishi, 1992). The iGluRs constitute a family of ligand-gated ion channels that are essential for mediating fast synaptic transmission in CNS. These receptors play an important role for the development and function of nervous system, and are key factors in learning and memory (Dingledine et al., 1998; Meldrum, 2000). They are critically important for normal brain function and are considered to be involved on neurological disorders and degenerative diseases such as schizophrenia, Alzheimer's disease, Parkinsons disease, brain damage following stroke and epilepsy as well as neuropathic pain (Medsen et al., 2005; Foster and Kamp, 2006; Bowie, 2008).

Ionotropic glutamate receptors (iGluRs) constitute a family of ligand gated ion channels subdivided into three classes distinguished by amino acid sequence, pharmacological profile, functional behavior and biological role (Armstrong and Gouaux, 2000). The iGluRs have been found to be homo- or heteromeric assemblies that form tetrameric ion channel complexes (Laube et al.,1998; Mano 
and Teichberg, 1998; Rosenmund et al.,1998). Those composed of GluA1-4 are activated by AMPA (amino-3-hydroxy-5-methylisoxazole-4-propionic acid) and are termed AMPA receptors, while Kainate has high affinity for KARs GluK1-5 (Coligrudge et al., 2009) and the third class are receptors activated byNMDA( $N$-methyl-D-aspartate). AMPA and glutamate evoke similar electrophysiological responses even though AMPA binds approximately 20 -fold more tightly than glutamate, depending on the receptor subunit (Brauner-Osborne et al., 2000). Functional NMDA receptors are composed of assemblies of the NR1 together with NR2A-D subunits (Hollman and Heinemann, 1994). The involvement of these receptors in neurological diseases has aroused widespread interest in their structure and function.

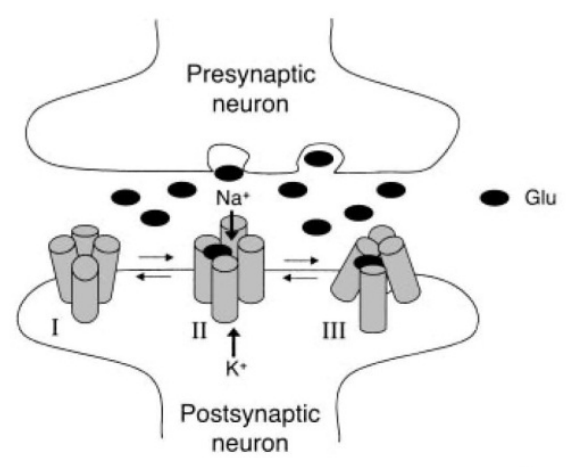

Fig. 1. A schematic representation of postsynaptic AMPA receptors. Postsynaptic AMPA receptors in the closed form in the absence of an agonist (I), in the open, agonist bound form (II), and in the desensitized form (III)

The iGluRs are membrane-bound and form tetramers assembled as dimers-of-dimers (Jin, 2003; Naur, 2005). Occupancy of the two binding sites is necessary for channel opening. There were four sites for agonist binding one in each subunit of the tetrameric assembly. From this and some other functional analysis is assumed that tetrameric assembly is formed through dimerisation of subunit monomers (via N-terminal domain) followed by dimerization of two subunit dimers (Ayalon and Stern-Bach, 2001). When the non-bounded receptor in apo state is attracted by an agonist both dimers are closing, the channel is opening and ion flow is enabled, but when antagonist is bound the dimers are in more open conformation compared to apo state and the ion flow is stopped by channel closure.

\section{Membrane topology}

Molecular organization of glutamate receptor subunit is presented on Fig. 2 and 3.

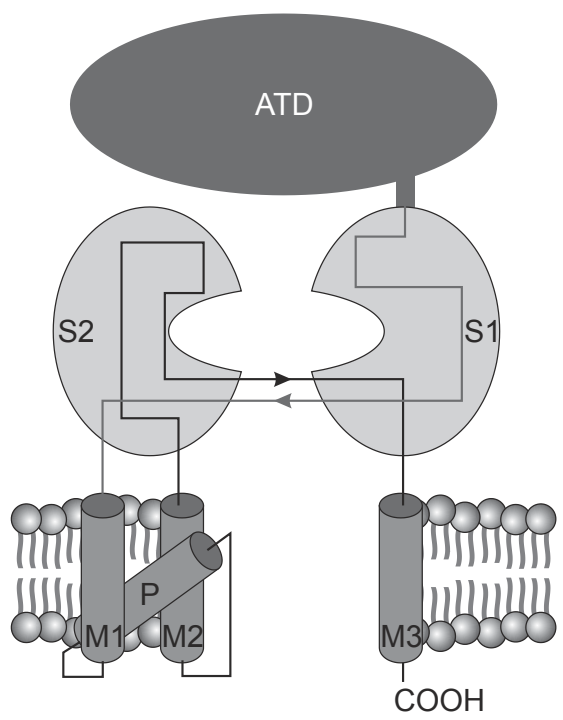

Fig. 2. Modular organization of a glutamate receptor. Membrane topology of an ionotropic glutamate receptor with three membrane spanning domains (M1, M3, and M4) and a re-entrant loop (P) and the amino(ATD) and carboxyl(CTD) terminal domain. The ligand binding domain is formed by the $\mathrm{S} 1$ and S2 regions of the protein which come together to form a hinged clamshell-like structure.

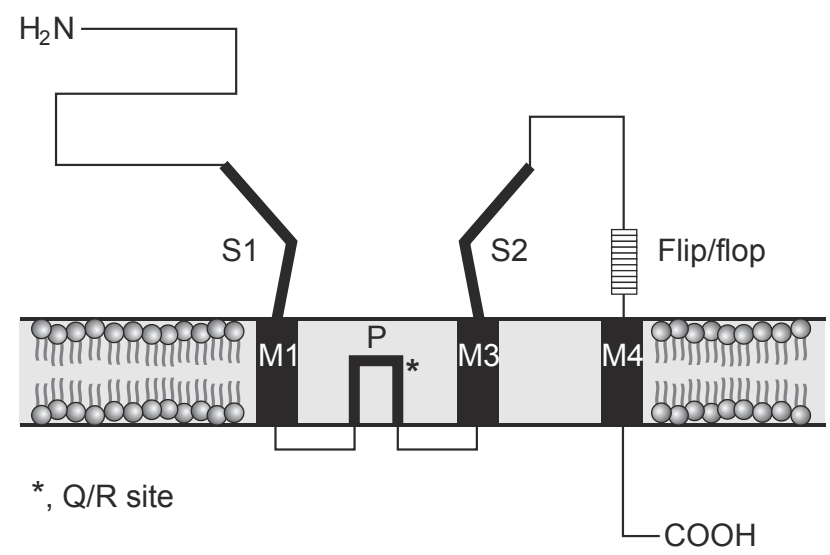

Fig. 3. Scheme of AMPA receptor subunits. The transmembrane topology is shown along with the flip/flop alternatively spliced exon, and the two ligand-binding domains (S1 and S2).

* is $\mathrm{Q} / \mathrm{R}$ editing site and glycosylation sites in the $\mathrm{N}$-terminal region. 
An amino terminal domain (ATD) is the site of action for a number of molecules that modulate glutamate receptor function (Herin and Aizenman, 2004) and structure-function studies have shown that this region is also involved in assembly of subunits within the receptor complex (SternBach et al., 1994; Ayalon and Stern-Bach, 2001). The ligand-binding domain consists of two regions termed S1 (N-terminal of M1 transmembrane spanning domain) and S2 (between regions M3 and M4) (Gouaux, 2004; Mayer and Armstrong, 2004; Mayer, 2005b). The hydrophobic membrane-associated region consists of three transmembrane spanning $\alpha$-helixes (M1, 3 and 4 ) and a reentry loop (M2; analogous to the P-loop found in voltage-gated potassium channels) and residues from this M2 region line the lumen of the ion channel pore and control ionselectivity and permeability (Wollmuth and Sobolevsky, 2004). An intracellular carboxy terminal domain (CTD) contains a number of structural motifs that allow the interaction with numerous signal transduction and scaffolding proteins and is important for correct regulation, trafficking and localisation of the receptor protein (Perrez-Otano and Ehlers, 2005). N-terminal half of AMPA receptor subunits are much less conserved than the sequence of C-terminal half. N-terminal segment has several sites appropriate for N-glycosylation (Everst et al., 1997), whereas C-terminal half of AMPA subunits has appropriate sites for phosphorylation (Roche et al., 1996).

\section{$N$-Terminal domain}

In AMPA and KA receptor subunits ATD does not bind glutamate but instead forms dimers that are major assembly control points limiting oligomerization to the members of the same iGluRs subfamily (Ayalon and Stern-Bach, 2001; Ayalon et al., 2005; Mayer, 2005b). Amino terminal domain is the site of action for a number of molecules, like allosteric modulators, that modulate glutamate receptor function.

In NMDA, the ATD is associated with $\mathrm{pH}$ sensitivity, glycine independent desensitization and regulation of receptor function by compounds like polyamines, histamine, $\mathrm{Mg}^{2+}$ and $\mathrm{Zn}^{2+}$ (Dingladine et al., 1999; Zheng et al., 2001; Mayer 2005b).

\section{Ligand-binding domain (S1S2)}

Two separate extracellular regions of approximately 150 residues each, $(\mathrm{S} 1)$ preceding the first membrane segment, and (S2) located between M3 and M4 segments, are interrupted by ion-channel pore (Stern-Bach et al., 1994; Mayer, 2005). The studies with chimeric AMPA/KA and NMDA receptor subunits have shown that this region (S1S2 ligand binding core) is important determinant of ligand pharmacology.

S1S2 binding region also contributes to AMPA receptor desensitization and redox modulation. Flip/flop seg- ment in C-terminal part of S2 affects the receptor desensitization (Fig.3) (Partin et al., 1994). This variants have small differences in ligand-binding properties (Nakanishi, 1992), different desensitization kinetics and different sensitivity to desensitization modulators CTZ (Partin et al., 1995) and PEPA (4-[2(phenylsulfonilamino) ethy [thio]2,6-difluoro-phenoxyacetamide) (Sekiguchi et al., 1997). The flip forms of most subunits desensitize more slowly and less profoundly than the flop forms.

Some of GluA2-4 AMPA subunits are edited at R/G site at an intronic site preceding the flip/flop exons. Replacing the glycine codon (IGA) with arginine codon (AGA) in GluA3 and GluA4 subunits also contributes to the kinetics of the glutamate evoked responses and speed up the recovery from agonist-induced desensitization (Lomeli et al.,1994). This is observed in GluA2, 3 and 4, but not in GluA1, due to the absence of the essential element that favors editing at the $\mathrm{R} / \mathrm{G}$ site (Fletcher and Lodge, 1996).

$\mathrm{S} 2$ region have two Cys residues corresponding to Cys744 and Cys-798 in NMDA receptor N1 which play impotent role in stabilization of the structure of ligand binding core of the iGluRs (Sutcliffe et al., 1996). This conserved cystein pair is responsible for $\mathrm{pH}$ sensitivity and binding of $\mathrm{Zn}^{2+}$ in NMDA receptors (Sullivan et al., 1994). S1S2 binding region of NR1 subunit of NMDA is bound to coagonist glycine, whereas the same region of NR2 is bound to glutamate (Kuratov et al., 1994; Laube et al., 1997).

\section{Transmembrane channel}

Some glutamate receptor RNAs are post-transcriptionally modified by RNA editing, which leads to single amino acid exchanges (Seeburg, 1996). RNA editing Q/R-site in M2 segment determinates the $\mathrm{Ca}^{2+}$ permeability of AMPA channels. All the AMPA receptor assemblies, that contain CluA2 subunit are $\mathrm{Ca}^{2+}$ impermeable and have linear steady-state current voltage relation, since GluA2 subunits are editing almost $100 \%$ and have Arg residue at $Q / R$ site (Hollman et al., 1991; Hume et al., 1991; Burnashev et al., 1992) (Fig. 3). Gln residue at $\mathrm{Q} / \mathrm{R}$ editing site is responsible for high permeability of GluA1, 3 and 4 subunits for $\mathrm{Ca}^{2+}$ and their inward rectification. The rectifying I-V relationship is blocked by intracellular polyamines, spermine and spermidine, which bind to the Gln at Q/R-site (Bowie and Mayer, 1995; Washburn and Dingledine, 1996). Similarly, blockage of $\mathrm{Ca}^{2+}$ permeable AMPA receptors by argiotoxin has been assigned to the Gln residue at the $Q / R$ site (Meucci and Miller, 1998). The GluA2 Q/R site is the most vigorously edited site. Physiological role, if any, of unedited GluA2 (Q) is unclear.

The M3 segment of AMPA receptors affects gating properties of the receptors. The mutation of Ala to Thr at a highly conserved C-terminal segment of the M3 at AMPA and KA receptor subunits makes the receptors continuously active or renders them to be activated by CNQX, normally an antagonist (Taverna et al., 2000; Schwarzet al., 2001). 


\section{C-terminal domain}

The greatest diversity among iGluRs subunits is found in their citoplasmatic domain, which varies in size from less than 20 to around 500 amino acids. The GluA1 subunit has a C-terminal domain of 81 amino acids, C-terminal domain of the GluA3 subunit is only 50 residues long (Keinänen et al., 1990). The GluA-2 and -4 subunits have either 68 or 50 amino acids in their C-terminal domains due to alternative splicing (Köhler et al.,1994). The C-terminal domain of KA receptors are of similar size to GluA1-4 subunits, where as the C-terminal domain of the NMDA receptor NR2 subunits are significantly larger, approximately 620640 amino acids (Sprengal and Seeburg, 1993). This is the key site of allosteric modulation by calcium/calomodulin kinase II (CAMKII), protein kinase $\mathrm{C}$ (PKC) protein kinase A (PKA) and phospatases and is potentially subjected to phosphorylation and dephosphorylation (Roche et al., 1996; Mayer, 2005b).

Functionally, this domain is involved in cytoskeletal interactions, subunit trafficking, and modulation of channel conductance and contains a variety of sites for post transcriptional/posttranslational modifications (McFeaters and Oswald, 2004).

\section{Mechanism of AMPA receptor activation and desensitization}

The binding of glutamate and other agonists to all glutamate receptors induces activation and opening of the transmembrane ion channel which is due to a conformational change in the receptor structure (Clements et al.,1998). Glutamate, as a natural agonist, is rapidly removed from synaptic cleft by uptake to glia cells or by diffusion, which leads to rapid closure of the channel by deactivation (Jonas, 2000). Deactivation caused by agonist appears after their dissociation. AMPA receptor activation occurs with the time constant of sub-milliseconds, whereas deactivation occurs in the time scale of one or two milliseconds. In high frequency stimulation, glutamate that is normally rapidly removed, may remain in the cleft for prolonged times. In the continuous presence of glutamate, and other agonist, the channel is closed by desensitization, which is particularly fast and strong forAMPA receptors and approximately three fold slower (1-6ms) than deactivation. The process of activation and desensitation of glutamate receptors is shown in Fig. 4. The extent of desensitization of the AMPA receptors depends on the type of agonist. L-glutamate and AMPA induce fast desensitisation (with a time scale of 1-6milliseconds), whereas kainate as partial agonist does not allow full desensitization of the AMPA receptors (Armstrong, 1998). Since the kainatebound structureis not fully closed, as AMPA- and glutamate-bound structures are, it seems that desensitization but not activation requires full closure of the binding domain (Armstrong and Gouaux, 2000).

In addition, the desensitized-state of the AMPA receptors show increased affinity to agonists. Desensitization appers to be a general mechanism of many ligand-gated

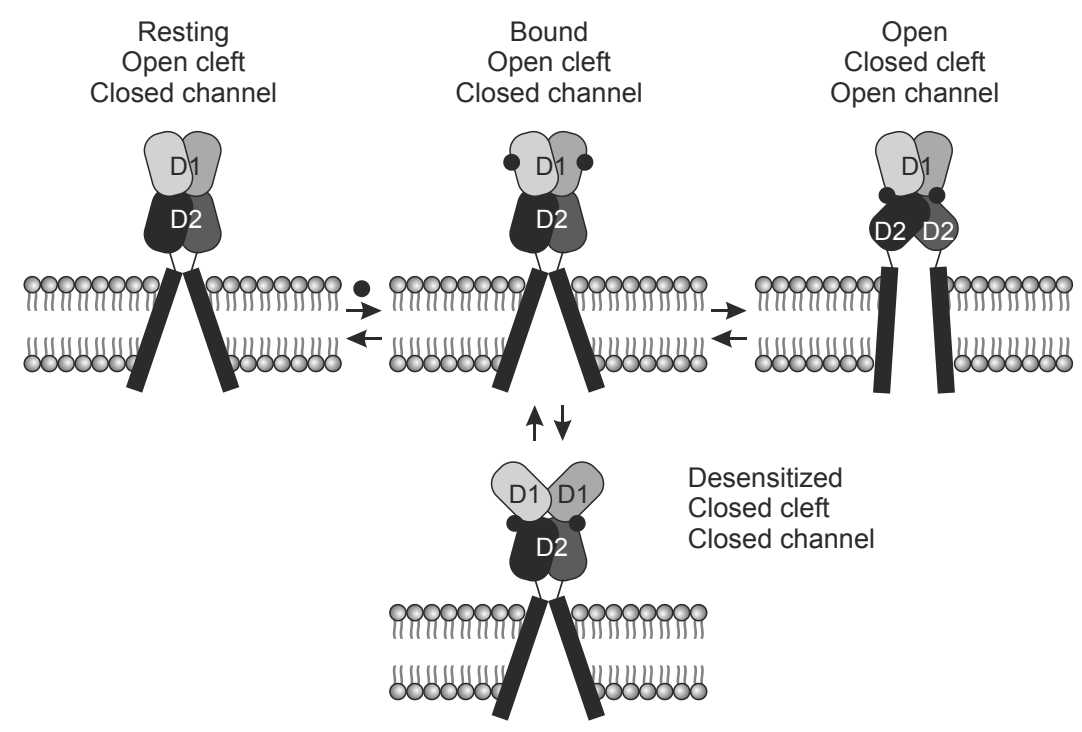

Fig. 4. A model for glutamate receptor activation and desensitization. Domain 1 and domain 2 of the ligand-binding core are labelled D1 and D2, respectively. Transmembrane segments of each subunit are indicated by a single cylinder and the N-terminal domain (ATD) has not been included in the model. Each subunit binds a single agonist (A, circle) and exists in three distinct conformations: closed (C), open (O)and desensitized (D). After the binding of agonist, closure of domain 2 towards domain 1 opens the channel gate, whereas closure of domain 1 towards domain 2 disrupts the dimer interface and desensitizes the receptor. The states are connected by using a simplified model for activation and desensitization, more complex versions of which quantitatively describe AMPA receptor responses. 
channels to cut ionflow into the cell in the presence of the ligand.

AMPA and KA receptors have conserved gating mechanisms and to desensitize, their ligand binding cores must undergo large conformational rearrangements. AMPA receptors recover from desensitization with time constants that are approximately 10 -fold faster than KA receptors, which is the one of the main kinetic distinctions between AMPA and KA receptors activated by the endogenous neurotransmitter glutamate (Dingdeline et al., 1999). The differences in extend of desensitization observed for glutamate versus kainate (Pataeau et al., 1992) is likely the result of differences in domain closure that in turn lead to differences in intersubunit contacts. KA receptors, which are fully activated by kainate, have a valine instead of leucine at the position equivalent to 650 in GluA2. Leu650Val mutant of GluA2 allows the ligand binding core to adopt a glutamate-like conformation in the presence of bound kainate, and in terms of desensitization, kainate acts on the mutant receptor as full agonist (Armstrong and Gouaux, 2000).

In comparison, NMDA receptors are activated with a time scale of 10-50 milliseconds. The deactivation anddesensitization also occurs with a much slower time course (in the time scale of tens orhundreds of milliseconds) than in AMPA receptors. The desensitization is complex, with variety of different processes that involved extracellular glycine, intracellular $\mathrm{Ca}^{2+}$ and certain intracellular proteins.

Crystal structure of iGluA2-S1S2 provides a new aspect of desensitization mechanism. Beside the subunit composition of receptor and type of bound agonist as explained previously, AMPA receptor desensitization kinetic is controlled also by alternative splicing affecting the flip/ flop region and the RNA editing of the R/G site (Dingledine et al., 1999).

\section{Crystal structure of the ligand-binding domain of GluA2}

Since the first publication in 1998 of structure of a recombinant soluble protein composing the ligand-binding domain of GluA2 extensive studies were performed in these families of receptors. Until recently, structural investigations were limited to studies of soluble constructs of individual domains, N-terminal domain (Jin et al., 2009) and the ligand binding domain (LBD) (Armstrong and Gouaux, 2000; Ahmed et al., 2009a and Kasper et al., 2008). Sobolevsky and coworkers in 2009 have solved the structure of the full-length homotetrameric GluA2 receptor. The determination was made at $3.6 \AA$ resolution in complex with the competitive antagonist ZK 200775 (pdbcode $3 \mathrm{KG}$ ). The receptor shows an overall axis of twofold symmetry but with the ion channel domain displaying four-fold symmetry. However, the soluble LBD protein is a good model system of the full length-receptor for studying binding of agonists and antagonists as well as binding of allosteric modulators at the dimer interface. Studies using radio-label binding assays (Armstrong and Gouaux, 2000; Hogner et al., 2002; Jin et al., 2003) have shown that GluA2 LBD has essentially identical properties to the corresponding domain in intact, membrane-bound protein.

The extracellular domains, defined as S1and S2 are joined together by a short, flexible peptide linker, replacing the membrane segments M1-M3 of the intact receptor. A large-scale production of histidine tagged S1S2 construct (HS1S2) by in vitro Escherichia coli expression was achieved by Chen and Gouaux, (1997). Gouaux and coworkers were able to confirm the 'clamshell' or 'venus fly trap' mechanism of the binding cleft when they obtained the first crystal structures of kainate-bound iGluA2-S1S2 fusion protein (Armstrong et al., 1998). This reaction involves initial rapid association of a ligand and a protein followed by a slower conformational rearrangement, which results in a structure with a ligand locked deeply in the binding pocket of the protein. In addition, this structure of the iGluA2-S1S2J fragment defined the location of the disulphide bond conserved in all iGluRs and the location of the conserved hydrophobic residues, predicted to form subunit-subunit contacts in the intact receptor. Crystallization of the ligand-bound protein allowed identification of unequivocally, key residues and water molecules, that interact with different ligands. iGluA2-S1S2 (denoted as S1S2I or $\mathrm{J}$ depending on the length of the interdomain peptide linker) crystals were found to existas dimerized subunits, implying that the tetrameric AMPA receptor complex may consist of a dimer of dimers configuration (Armstrong and Gouaux, 2000).

\section{Agonist binding in the GluA2-LBD}

In GluA2 domain 1 is composed of the N-terminal part of S1 and a short C-terminal segment of S2, and domain 2 is composed mostly of the S2segment and a short C-terminal segment of the S1 (Armstrong et al., 1998). Both are $\beta$-plated sheet surrounded by $\alpha$-helices. As shown in the picture below domain 1 is formed by six $\alpha$-helices: A, $\mathrm{B}, \mathrm{C}$ and D from S1 segment, and $\mathrm{J}$ and K-helices, which are formed by $\mathrm{S} 2$ segment. Domain 2 forms $\alpha$-helices: E, F, G, H and I (Armstrong and Gouaux, 2000).

Structure of flop variant of GluA2 LBD with (S)glutamate was first solved by Armstrong and Gouaux (2000) and later by Ahmed et al., 2009a. Structure of flip variant of GluA2 LBD with (S)-glutamate was published by Gregor et al., 2006. Since 1980, when Krogsgaard -Larsen and coworkers, reported that AMPA is bioisoster of glutamate and a very potent excitant when applied in CNS and spinal cord, and its selectivity towards GluA1-4 over other GluRs led to definition of class of AMPA receptors (Foster and Fagg, 1984; Olsen et al., 1987; Waterkins et al., 1990), structures of GluA2 with AMPA and seven other isoxasol containing agonists have been published (Armstrong and Gouaux, 2000; Hogner et al., 2002; Kasper et al., 2002; Lunn et al., 2003; Nielsen et al., 2005; Vogensen et al., 2007). 
There are 20 key residues in S1S2 binding pocket that are responsible for interactions and rearrangements in the binding pocket (Lunn et al., 2003). According to the 'Venus fly trap' mechanism, the ligand first interacts with the side chains of residues Tyr450 and Glu402 of the S1. In the second step, slower one, S1S2 changes its conformations and forms a hydrogen-bond network between the ligand and both protein domains S1 and S2 (Armstrong et al., 1998; Abele et al., 2000).

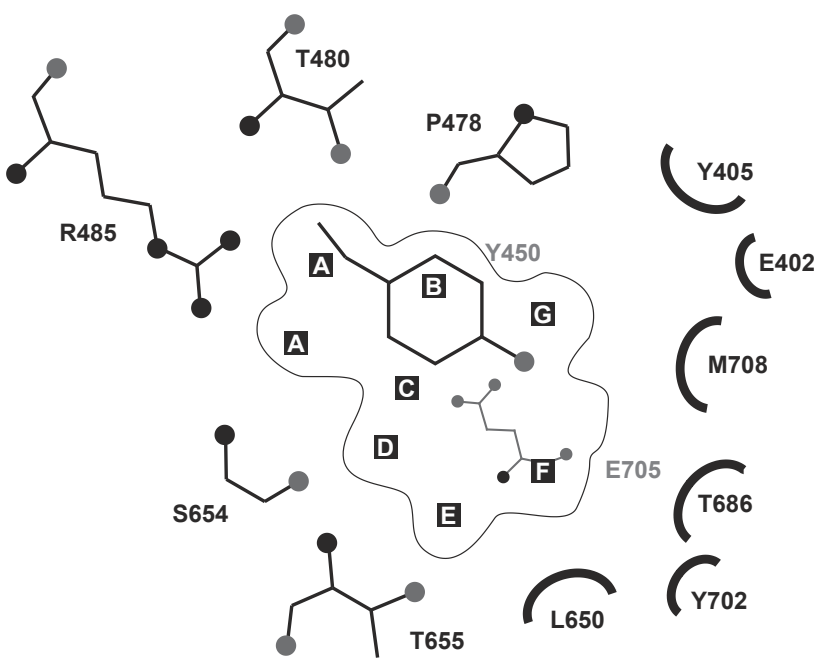

Fig.5. Schematic presentation of the agonist binding site. Forsimplicity, to represent the 3D natureof the binding cleft, Tyr450 and Glu705 are shown over and under the agonist subsites, respectively. Subsites (A, D, E, and F) are occupied by hydrogen bond acceptors, while subsite B is occupied bya hydrogen bond donor.

The schematic diagram of amino acids of the LBD that are responsible for interacting with ligands is presented in Fig. 5. $\alpha$-carboxilate and $\alpha$-amino groups of the ligands can be responsible for the ligand recognition because they become largely desolvated and bind directly to the protein. These groups interact with the ligand binding core through 7 hydrogen and ion-pair bonding interactions to domains 1 and 2. Three residues from the S1 domain (Pro478, Thr480 and Arg485) and from the S2 domain (Ser654, Thr655 and Glu705) make direct hydrogen bonds with glutamate.Two hydrogen bonds are formed with guanidinium group of the Arg485 residue. Negatively charged $\alpha$-carboxiyl group is bound by hydrogen bonds and electrostatic interactions to this residue. Kinetic experiments with mutants of the Arg485 residue leads to complete loss of the channel function; thus the presence of this group is important for ligand binding (Spasenskiy and Kurnikova, 2005). $\alpha$-carboxyl group of the ligand is also hydrogen bonded to the backbone NH-group of Thr480 and Ser654.

Negatively charged Glu705 is the primary source of the negative potential at the position of the positively charged $\alpha$-amino group of the ligands. Amino acids
Glu705 and Thr480 are responsible for the formation of a three-way hydrogen-bond network with the $\alpha$-amino group of the glutamate ligand. Side chain hydroxyl of Thr480 and carboxylate of Glu705 make strong hydrogen bonds with $\alpha$-amino group. This triangular network connects the two domains of the protein and is important for stabilizing the protein-ligand complex, e.g.,glutaric acid in which $\alpha$-amino group is absent does not bind to iGluRs (Abele et al., 2000). $\alpha$-amino group is also hydrogen bonded to the backbone carbonyl oxygen of Pro478 (Armstrong and Gouaux, 2000).

Thearomatic side chain of Tyr450, while not directly hydrogenbonding with glutamate, forms an electron-dense ring structure above the ligand-binding pocket and mutations of this tyrosine residue with smaller alanine or larger tryptophan, alter agonist potency and desensitization kinetics in GluA2-containing receptors. In the S1S2J-(S)glutamate complex Tyr450 $(\mathrm{OH})$ forms a hydrogen bond with Glu402 (OE2), thereby stabilizing the interdomain interaction between Glu402 and Thr686. Tyr450 can only weekly stabilize Glu402 in the kainate complex. Because Tyr450Thr mutation disrupts the hydrogen bond between Tyr450 and Glu402 this might affect the potency of glutamate in a greater extent than for kainate.

GluA2 residue Met708 is flexible residue that undergoes major conformational changes (induced fit) to optimize van der Waals stabilization of the bound agonist. This allows the hydrophobic pocket to change in size in order to accommodate substituents of various sizes.

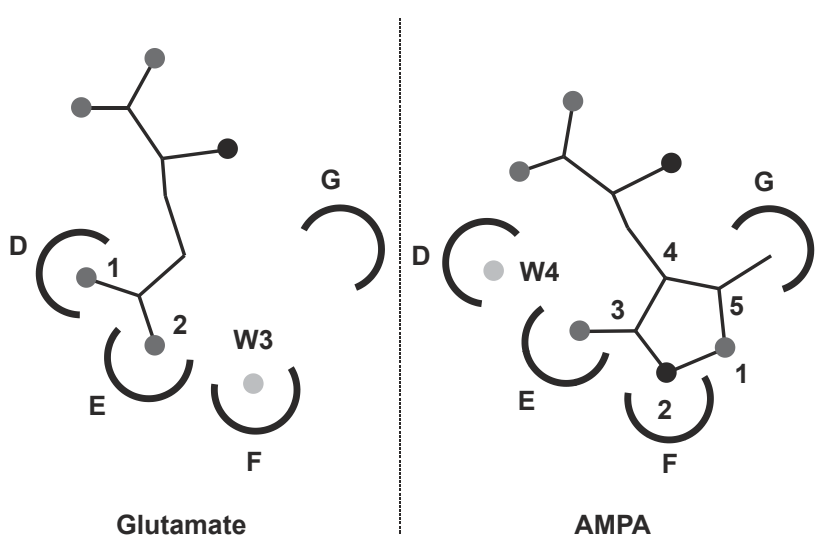

Fig. 6. Modes of Agonist Binding. Subsite binding regions occupied by the $\gamma$-carboxylate of glutamate and water W3. Subsite binding regions occupied by the isoxasolering of AMPA and water W4. Water molecules are shown as spheres. The subsites include the following residues and atoms: Ser654 $\mathrm{NH}$ and Thr655 NH of subsite D, Thr655 OH of subsite E, Glu705 NH of subsite F, side chains of Glu402, Tyr450, Pro478, Glu705, Met708 and Tyr732 of subsite G.

The " $\gamma$ " group binding pocket is composed of four subsites (D, E, F, and G in Fig. 6). Subsites D and E are 
located at the base of helix F. The distal anionic group of the iGluA2 agonists is hydrogen bounded to the base of $\alpha$-helix (helix F). The hydrogen bonds are formed by the backbone NHgroups of Ser654 and Thr655, the hydroxyl of Thr655, a water molecule bound to the base of helix F (water 3), and a water molecule (2) tethered to the NH group of Leu650 and the carbonyl oxygen of Leu703. While the $\gamma$-carboxyl groups of glutamate and kainate interact with the same subsites (hydroxyl and backbone-NHgroups of Ser654 and Thr655 and two water molecules), theisoxazole group of AMPA interacts differently, binds in subsites E, F and G and subsite D is empty (normally occupied by the $\gamma$-carboxyl group of glutamate or kainate). In the case of AMPA, a water molecule (4) is recruited to this unoccupied subsite D thus enabling AMPA tobehave like a bioisosteric mimic of glutamate (Armstrong and Gouaux, 2000). This water molecule makes close interaction with isoxazole hydroxyl (2.45 $\AA$ ), an $\alpha$-carboxyl oxygen, and residues at the base of helix $\mathrm{F}$.

The four water molecules surrounding the aria around distal anionic group form a network that establishes indirect hydrogen bonds between the ligand and side-chains of amino acids within the partially hydrophobic pocket and are essential for the ligand binding and for determination of receptor subtype specificity.

The agonists adopt the two different binding modes, glutamate-like or AMPA-like. The size of the substituent in the 5-position of the isoxazolol ring is a major determinant of the ligand-binding mode for AMPA-type agonists. A large substituent results in a glutamate-like binding mode, whereas small or no substituents leads to AMPA-like binding.The isoxazolol moiety is not able to control thebinding mode (Kasper et al., 2002).

All of 20 amino acid residues in the biding pocket except Tyr702 are conserved among AMPA receptors. Banke et al. 2001 identified this nonconserved Tyr residue in AMPA preferring subunits as being the main contributor to the selectivity of $(S)$-Br-HIBOfor GluA1 over GluA3. In GluA1, this residue is conserved (Tyr698), whereas it is a phenylalanine (Phe706) in GluA3. There is a previously reported structure of a single-pointmutant of the iGluA2-S1S2J construct, (Tyr702Phe) iGluA2-S1S2J, in complex with (S)-Br-HIBO (Hogner et al., 2002). This mutation accounts for an 18-fold decrease in affinity for $\mathrm{Br}$ HIBO (Banke et al. 2001). The AMPA analogue Br-HIBO has been identified as a subtype-selective agonist among AMPA receptors, differentiating the homomeric receptors GluA1o from GluA3o by a ca70-fold difference in affinity of the racemate (Coquelle et al., 2000).

\section{Domain closure}

In the resting state (apo structure; pdb-code1FTO), the GluA2 LBD is in an open state (Armstrong and Gouaux, 2000). When the ligand is interacting with the iGluR2S1S2J protein an increase in the angle of domain closure compared to the unliganded (apo) conformation is observed between the twov binding lobes. This domain closure results in the opening of ion channel in full-length receptor (activation). The electrophysiology experiments obtained an excellent correlation between agonist-induced domain closure of the GluA2 LBD, linker-linker (Ile633-Ile633) distance and compound efficacy.

Great increase in domain closure of the clamshell was observed for full agonists $\left(20-22^{\circ}\right)$ and this correlates with agonist efficacy, while partial agonists inducing a degree of domain closure inbetween those induced by full agonists or antagonists, (13-19 $)$. (Armstrong and Gouaux, 2000; Hogner et al., 2002; Jin et al., 2002; Armstrong et al., 2003). This is best exemplifiedby a series of 5-substituted willardiines that differ in the size of a halide substituent, for which an increase in substituent size sterically hindered domain closure in a graded fashion (Jin et al., 2003). In agreement with the evidence that partial agonists induce less domain closure than full agonists, molecular dynamics simulations have shown that partial agonists such as kainate are held less rigidly within the iGluR2 pocket than full agonists (glutamate) and, as a consequence of this, water mobility at specific subsites within the pocket is agonist dependent (Arinaminpathy et al., 2006).

In general terms, the rotation describing the domain closure motion occurs about an axis that runs through the two inter-domain $\beta$-strands and along helix I from domain 2. Helix I from domain 2 reorients with domain 1, while remainder of domain 2 moves as a separate rigid body, because helix I is linked via a disulfide bond to domain 1. The center of rotation deffers in the apo to kainate transition compared to the apo to AMPA/glutamate transition. The peptide segment Asp651-Gly653 has been shown to undergo a rearrangement of the backbone upon the transition from the open state (apo) to the fully closed state (e.g. AMPA) (Armstrong and Geuoux, 2000). The trans peptide bond connecting Asp651 and Ser652 undergoes a $\sim 180^{\circ}$ flip relative to its orientation in the kainate, DNQX and apo structure. Neither of the residues Asp651 and Ser652 nor Glu653 are in direct contact with the ligands, but the surrounding residues Leu650 and Ser654 make hydrogen bonds / van der Waals interactions with the agonists. The peptide bond rearrangement results in two additional hydrogen bonds between domain 1 and 2 in the AMPA-bound state; the backbone carbonyl of Ser652 hydrogen bonds to the backbone amide of Gly451, and a water-mediated hydrogen bond connects the backbone carbonyl of Asp651 to the backbone amide of Tyr450 (Hogner et al., 2002). The isopropenyl group of kainate acts as a 'foot in a door' colliding with Tyr450 from domain 1 and with van der Waals contact with Leu650 in domain 2, thus preventing domain 2 from moving to a glutamate-like position (Armstrong and Gouaux, 2003). A correlation between peptide flip and relative domain closure has been suggested, as a large degree of closure (e.g. $20^{\circ}$ for (S)-AMPA relative to the apo structure) has been observed in conjunction with a flipped 


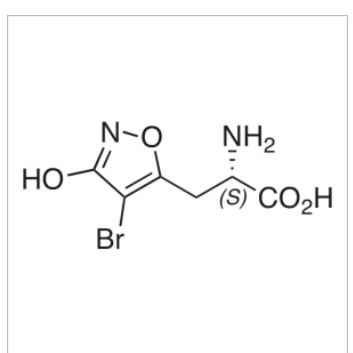

AMPA

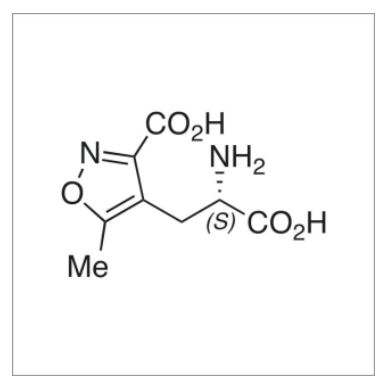

2-Me-Tet-AMPA

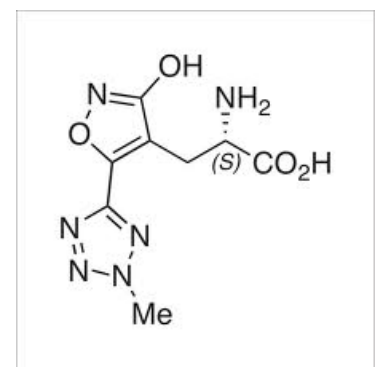

ACPA

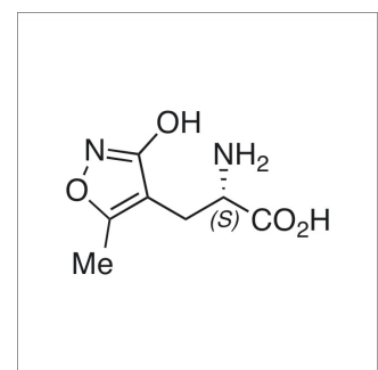

$\mathrm{Br}-\mathrm{HIBO}$

Fig. 7. GluA2 agonists. Compound names: AMPA- 2-amino-3-(5-methyl-3-oxo-1,2- oxazol-4-yl)propanoic acid; 2-MeTet-AMPA 2-methyl-tetrazolyl-[2-amino-3-(3-hydroxy-5-methyl-4-isoxazolyl)propionic acid]; ACPA-(S)-2-amino3-(3-carboxy-5-methylisoxazol-4-yl)propionic acid; Br-HIBO-(S)-2-amino-3-(4-bromo-3-hydroxy-isoxazol-5-yl) propionic acid

peptide bond, in contrast to less closed structures (e.g. $12^{\circ}$ in kainate).

Agonists (Fig. 7) can be divided into two groups with respect to the peptide conformation, except for glutamate, which induces multiple conformations. The first group consists of the three high-affinity agonists 2-Me-Tet-AMPA, ACPA, and AMPA which all induce full domain closure relative to the apo structure. The second group consists of the lower-affinity agonists $\mathrm{Br}-\mathrm{HIBO}$ and $\mathrm{KA}$, as well as the antagonist DNQX, which all stabilise the unflipped conformation and induce less domain closure. The peptide segment is located just before the two key residues Ser654 and Thr655, which are involved in ligand interactions; however, none of the residues involved in the peptide flip is in direct contact with the ligands (Hogner et al., 2002).

\section{Binding antagonists and comparison of ATPO, DNQX and NS1209 with GluA2-S1S2LBD binding mode}

The development of antagonists for glutamate receptor subtypes is a great interest because of their neurortective action of variety of neurodegenerative disorders. Today, structures of eight antagonists presented on Fig. 8 in complex with the GluA2 LBD are published. The relative domain closure made by these antagonists in comparison to non-bounded apo structure is presented in Table 1. It is important to stress that all antagonists prevent the formation of an important D1-D2 interdomain contact between Glu402 and Thr686 (Armstrong and Gouaux, 2000).

The antagonists FQX, CNQX, DNQX and ATPO make small domain closures from 2.5 to $8.1^{\circ}$, whereas (S)NS1209, UBP282 and ZK200775 lead to $4.3-9.6^{\circ}$ of hyper-

\section{Antagonists}<smiles>CC1(C)[NH2+]C(C(=O)O)Cc2c(OCP(=O)(O)O)noc21</smiles>

ATPO

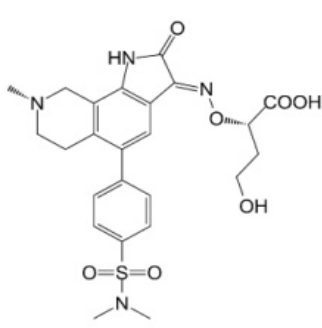

NS1209<smiles>N#Cc1cc2[nH]c(=O)c(=O)[nH]c2cc1[N+](=O)[O-]</smiles>

CNQX<smiles>NC(=O)C(CN1CC=CC(=O)N1CCC(=O)O)C(=O)O</smiles>

UBP277

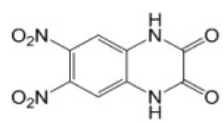

DNQX

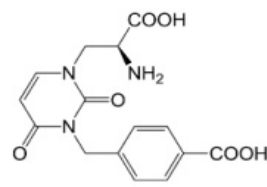

UBP282<smiles>CC(=O)Nc1cc2[nH]c(=O)c(=O)[nH]c2cc1C</smiles>

FQX<smiles>O=c1[nH]c2cc(C(F)(F)F)c(N3CCOCC3)cc2n(CP(=O)(O)O)c1=O</smiles>

ZK 200775

Fig. 8. GluA2 antagonists. Compound names: ATPO: 2-amino-3-[5-tert-butyl-3-(phosphonomethoxy)-4-isoxazlyl]propionic acid; CNQX; 6-cyano-7-nitroquinoxaline-2,3-dione; DNQX: 6.7-dinitroquinoxaline-2,3-dione; FQX:[1,2,5] oxadiazolo[3,4-g] quinoxaline-6,7(5H,8H)-dione 1-oxide; NS1209: 8-methyl-5-(4-(N,N-dimethylsulfamoil)phenyl)6,7,8,9-tetrahydro-1H-pyrrolo[3,2,h]-isoquinoline-2,3-dione-3-O-(4-hydroxybutyrate-2-yl)oxime; UBP277; 3-(2carboxyethyl)willardine; UBP282: 3-(4-carboxybenzyl) willardine; ZK200775: [1,2,3,4-tetrahydro-7-morpholinyl2,3-dioxo-6-(trifluoromethyl)quinoxalin-1-yl]methylphosphonate 
Table 1. Relative domain closure made by antagonists binding for iGluA2

\begin{tabular}{|c|c|c|c|c|}
\hline Antagonist & Agonist & Domain closure (deg. $)^{\mathrm{a}}$ & PDB codes ${ }^{b}$ & References \\
\hline ATPO & & $2.5-5.1$ & 1NOT & Hogneret al. (2003) \\
\hline CNQX & & $6.0-8.1$ & 3B7D & Menuz et al. (2007) \\
\hline DNQX & & $3.4-6.5$ & 1FTL & Armstrong and Gouaux (2000) \\
\hline FQX & & $3.4-5.5$ & 3BKI & Cruz et al. (2008) \\
\hline NS1209 & Glutamate & $-5.4(22.4)$ & $2 \mathrm{CMO}$ & Kasper et al. (2006) \\
\hline UBP277 & & $-4.3-(-6.4)\left(B . G^{c}\right)$ & $3 \mathrm{H} 03$ & Ahmed et al.(2009b) \\
\hline UBP282 & & $-5.6-(-9.6)\left(J L N P^{d}\right)$ & $3 \mathrm{H} 06$ & Ahmed et al. (2009b) \\
\hline ZK200775 & Glutamate & $(22.7)^{\mathrm{e}}$ & $3 \mathrm{KGC}$ & Sobolevsky et al. (2009) \\
\hline
\end{tabular}

a Domain closure was calculated relative to the apo structure od GluA2 LBD (pdb-code 1FTO, molA) using DynDom (Hayward and Berendsen, 1998).

${ }^{\mathrm{b}}$ Structures deposited in the Protein Data Bank.

${ }^{\mathrm{c}}$ Domain closure could only be calculated for molecules B and G using DynDom.

${ }^{\mathrm{e}}$ Domain closure could only be calculated for molecules J, I, N and P using DynDom.

${ }_{\mathrm{f}}^{\mathrm{f}}$ Domain closure could not be calculated for molecule containing the antagonist using DynDom.

(a)

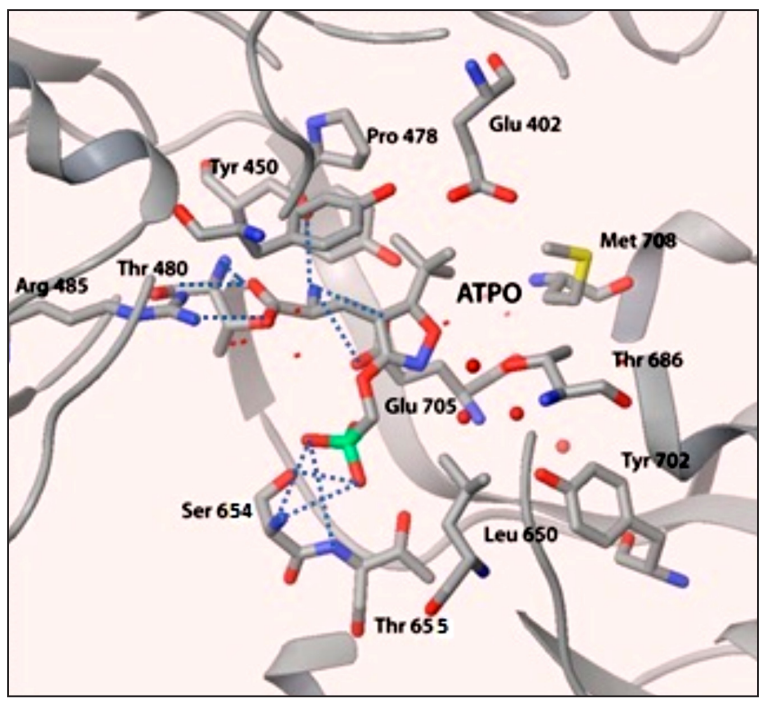

(b)

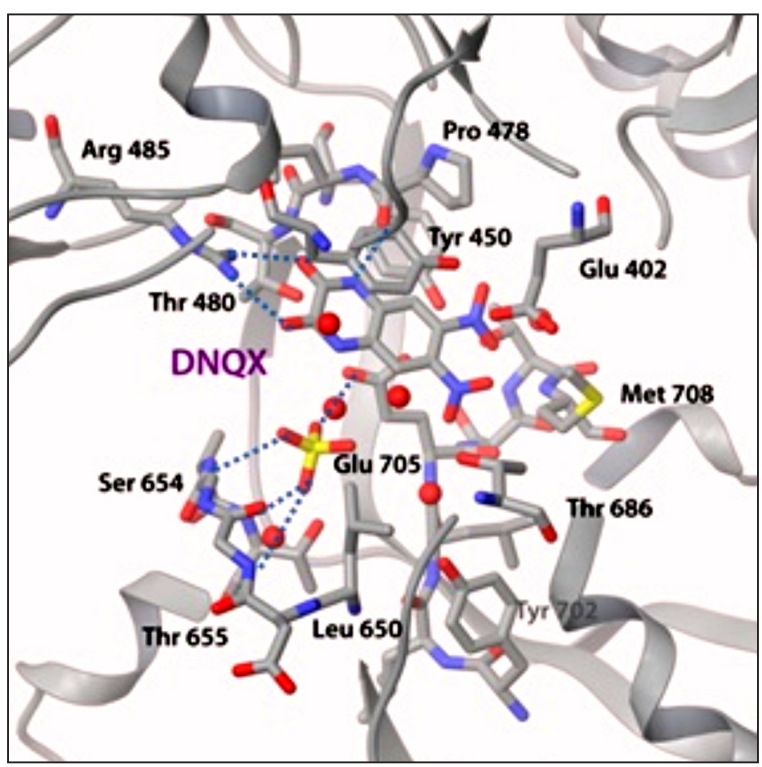

Fig. 9. (b) DNQX -GluA2-S1S2J binding mode. DNQXGluA2-S1S2J binding mode extension of the LBD in comparison to the apo unbounded structure due to steric hindrance(Pǿhlsgaard et al., 2010).

(RS)-NS1209 is a glutamate antagonist which differs in binding and structure from two previously characterized antagonists ATPO and DNQX. One interesting finding for this ligandis that the two protein molecules were observed in the asymmetric unit of the crystal structure of (S)-NS1209. In one molecule, the antagonist (S)-NS1209 is bound within the ligand-binding cleft, whereas the agonist (S)-glutamate is bound to the other protomer (Kasper et al., 2006).A similar mixed dimer was published for antagonist ZK200775 which is bound in one of the protomers (Sobolevski et al., 2009).

The antagonists UBP277 and UBP282 are derivate of naturally occurring willardine. These two antagonists bind to domain D1 in a similar manner to the agonists, but differences in binding to D2 residues lead to differences in the position of the uracil ring. UBP277 introduces a domain closure similar to that of (S)-NS1209, whereas the binding of UBP282 produces the largest hyperextension of domains D1 and D2 yet reported for an AMPA receptor (Ahmed et al., 2009b). The carboxyethyl moiety of UBP277 and the carboxybenzyl moiety of UBP282 keep the domains separated by a "foot-in-the-door"mechanism(Pøhlsgaard et al., 2010).

Quinoxalinedione compounds, CNQX and DNQX are the most commonly used AMPA receptor antagonists. They induce a small domain closure in GluA2 LBD of 6.08.1 and $3.4-6.5^{\circ}$, respectively.

In the crystal structure of ATPO and DNQX the ligands are bonded in the both protomers although some differences are observed in the bounding conformations. In the Fig. 9 ( $\mathrm{a}$ and $\mathrm{b}$ ) and 10 are presented the binding modes of these three antagonists.

Conserved group of residues Pro478, Thr480 and Arg485 from domein 1 and Glu705 from domein 2 make similar interactions with all three antagonists. $\alpha$-carboxylate and the $\alpha$-ammonium groups of ATPO overlay well with the two carbonyl groups and one of the amide nitrogens 
of the quinoxalinedione ring of DNQX. The two carbonyl groups mimic $\alpha$-carboxyl group common to ATPO and agonists, forming hydrogen bonds to Arg485 and the hydroxyl and backbone amide of Thr480. A DNQX amide nitrogen and $\alpha$-ammonium group of ATPO makes a hydrogen bond to the backbone carbonyl of Pro478.

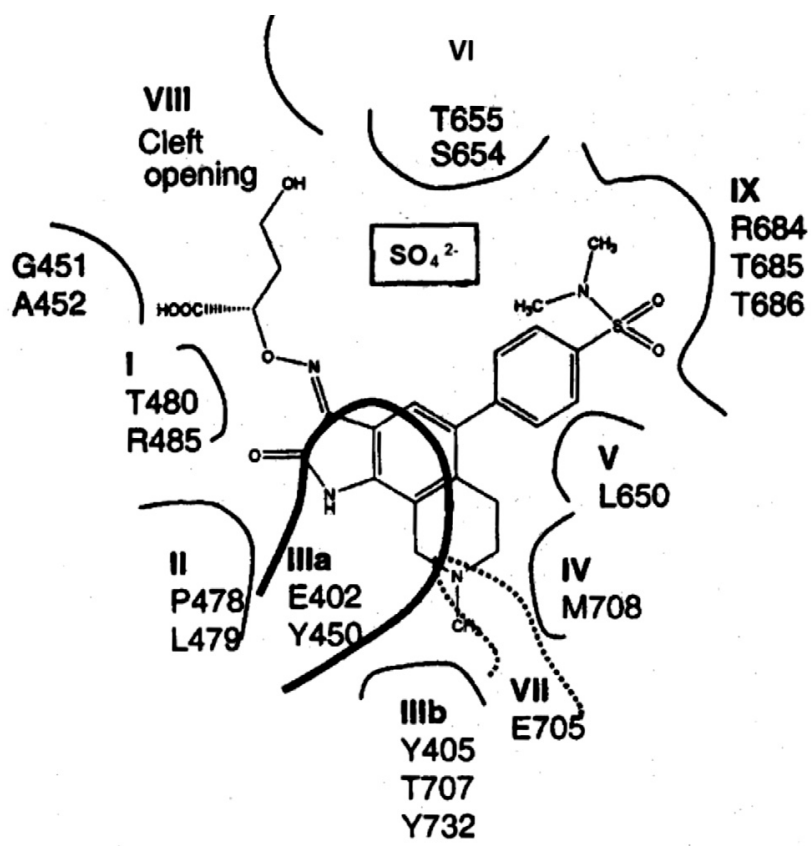

Fig. 10. (S)-NS1209-GluA2-S1S2J binding mode

As it is shown on Fig.10 the oxime nitrogen as well as the carbonyl oxygen atoms and the nitrogen atom of the pyrole ring of (S)-NS1209 mimic the $\alpha$-carboxylateand $\alpha$-ammonium groups and they make comparable interactions with the conserved residues of domain 1 (Kasper et al., 2006). The interaction with domain1 is further stabilisedby two additional hydrogen bonds formed between (S)-NS1209 and the amino acid residues Tyr450 and Gly451. These two bonds have not been observed in any other antagonist or agonist complexes solved so far. Water molecules located at positions corresponding to W1 in the (S)-NS1209 structure are observed also in the (S)ATPOand DNQXstructures. In the latter two cases, this water molecule forms a hydrogen bond to the main-chain nitrogen atomof Tyr450, whereas in the (S)-NS1209 structure, thewater molecule is directly hydrogen bonded to the antagonist (Kasper et al., 2006).

The side-chain conformations of Tyr450, Glu705 and Met708 are different in NS1209 from those that found in the (S)-ATPO and DNQX structures. DNQX is binded near the top of the cleft. The quinoxalinedione ring of DNQX lays $\sim 3.6 \AA$ directly below and parallel to the aromatic ring of Tyr450, thus maximizing $\pi$-stacking interactions.As a due to the presence of the bulky phenyl sulfonamide substituent in (S)-NS1209, this antagonist is positioned closer towards D1 and makes even closer $\pi-\pi$ overlap with
Tyr450 than DNQX or (S)-ATPO (Fig.10).

The side-chain of Glu705 normally interacts with the $\alpha$-amino group of ligands derivedfrom amino acids (Armstrong et al. 1998; Hogner et al. 2003; Jin et al. 2003;). Glu705 adopts different positions in the protomer A and protomer B of DNQX-GluA2 complex. It adopts an extended conformation in protomer B with the $\gamma$-carboxyl group directly under the quinoxalinedione rings, while in the protomer A the $\gamma$-carboxylof Glu705 is bent slightly away from DNQX. In (S)-NS1209 $\gamma$-carboxylate group of Glu705 adopts a different conformation compared to corresponding atoms in the (S)-ATPO and DNQX structures, and forms an ion pair interaction with N3 of (S)-NS1209. In addition, the Glu705 side-chain is hydrogen bonded to a novel water molecule, $\mathrm{W} 2$, whose position corresponds to the OE2 atom of Glu705 in the (S)-ATPO and DNQX structures. The side-chain OE2 atom of Glu705 forms hydrogen bonds to both the $\alpha$-ammonium group of ATPO and to the oxygen $\mathrm{O} 4$ of the phosphonate group, implying that $\mathrm{O} 4$ is protonated.

In GluR2 complexes, Met708 adopts a wide variety of conformations to optimise its van der Waals interactions with the bound ligand. Theside-chain conformation of Met708 is the same in the DNQX and (S)-ATPO structures, pointing away from the ligands, where as it leans towards the ligand in the (S)-NS1209 structure. Met708 is also in van der Waals contact with Thr686. As with (S)-ATPO and DNQX, (S)-NS1209 acts by competitively occupying the binding site, while hindering D1-D2 domain closure and by stabilisingan open form of the ligand-binding core. The phenyl sulfonamide moiety of (S)-NS1209 functions in two ways. Firstly, it takes effect by sterically hindering domain closure and pushing D1 and D2 apart. Secondly, it acts via hydrogen bonding to a residue of D2. O7 of the sulfonamide moiety of (S)-NS1209 is hydrogen bonded to the backbone nitrogen and potentially also to the sidechain oxygen atom of Thr686. (S)-NS1209 (like DNQX, molecule A) interacts directly with a residue of the lock through hydrogen bonding and stabilises the open form by preventing an interdomain interaction between Glu402 in D1 and Thr686 in D2 essential residues for stabilising the activated domain-closed form of the receptor (Armstrong et al., 2000; Jin et al., 2003; Nilsen et al., 2005). The phenyl group probably acts as a spacer and serves to increase affinity by displacing loosely bound water molecules. It is also within van der Waals interaction range of residues of both D1 and D2.

The isoxazole ring of ATPO forms only a single, indirect interaction with the protein,from the nitrogen atom via a water molecule W2 to Glu705 and it plays a role of a spacer in the binding pocket (Hogner at al., 2003).

The bulky tert-butyl group at the 5-position of the isoxazole ring in ATPO is partly buried in a pocket formed by residues Glu402, Tyr405 and Tyr450 of domain 1 and Glu705, Thr707, Met708 and Tyr732 of domain 2. The 6-nitrogroup of DNQX interacts with Tyr-732 and a pro- 
tein-bound water molecule, and the 7-nitro moiety is hydrogen bondedto the hydroxyl of Thr-686(2.95 $\AA$ ) (Fig. 9 $\mathrm{a}$ and $\mathrm{b})$.

The phosphonate group of ATPO is involved in anextensive hydrogen bonding network, interacting directly with Ser654, Thr655, and Glu705, and forming indirect contacts with the protein through six water molecules The side-chain of Glu705 forms hydrogen bond to the oxygen O4 of the phosphonate group. (Hogner et al., 2003). The phosphonate group of ATPO appears approximately at the same position as the sulfate ion in the S1S2J:DNQX-B (Armstrongand Gouaux, 2000) and GluR2-S1S2J:(S)NS1209 (Kasper et al., 2006) complexes. This indicates that the protein environment in this region is favorable for accommodating a large negatively charged group. Also a water molecule is located between DNQXand the bound sulfate in the crystal structure. The sulfate interacts with helix F via 3 hydrogen bonds to the protein and 3 hydrogen bonds to solvent molecules, mimicking the interactions that the anionic "R" groups of agonists make with the base of helix F. The hydroxy group of (S)-NS1209 makes a hydrogen bond to this sulphate ion, which again forms hydrogen bonds to Ser654 and Thr655. Unlike (S)-ATPO, (S)NS1209 makes no direct interactions with Thr655 (Kasper et al., 2006).

Interestingly, three water molecules in the (S)ATPO structure correspond to hydrogen-bonding atoms (O1, O3, O4) of (S)-NS1209 (although O4 is only a weak acceptor).These oxygen atoms are all from the 4-hydroxybutyratemoiety of (S)-NS1209, which reaches out into the opening of the ligand-binding cleft. This indicates that these are favoured positions for a hydrogenbonding donor or acceptor, and that (S)-NS1209 can replace water molecules at thesepositions.

(S)-NS1209 occupies a new site IX where the phenyl sulfonamide moiety is embedded, and this site is bounded by residues Arg684, Thr685 and Thr686. This part of the molecule is positioned in an area of the cleft that has been unoccupied in all previously solved complex structures (agonists and antagonists).

Antagonists prevent further domain closure by different mechanisms. Even though ATPO and DNQX occupy different volumes of the binding site, both ligands fulfill the criteria for an antagonist. ATPO stabilizes the open cleft via direct interactions between the phosphonate group and residues in the base of the helix F much like the sulfate anion in the GluR2-DNQX complex in domain 2. At the same time, the tert-butyl group is accommodated within the pocket formed by residues in domain 1 and domain 2 . Thus, further domain closure is prevented by steric interference between the receptor and the tert-butyl group onone hand, and between the phosphonate moiety and domain 2 on the other.

By contrast, the 6-nitro groupof DNQX prevents an interdomain interaction between Glu402 in domain 1 and Thr686 in domain 2 and forms a long hydrogen bond (3.5
$\AA$ ) to Thr686. In the closed agonist induced conformationof S1S2J, these two residues interact strongly (Hogner et al., 2002). By occupying the ligand binding cleft near the axis of rotation that describes the relative movement of domains 1 and 2 in the apo to AMPA transition, DNQX stabilized the open cleft conformation via antagonist receptorinteractions.

(S)-NS1209 is the only competitive antagonist that stabilized even more open conformation of D1 and D2 domains of the ligand binding core than that of the apo structure due to a steric hindrance. Sulfonamide moiety of (S)-NS1209 is hydrogen bonded to the backbone nitrogen and potentially also to theside-chain oxigen atom of Thr686. (S)-NS1209, like DNQX, interacts directly with a residue of the lock through hydrogen bonding and stabilises the open form by preventingan inter domain interaction between Glu402 in D1 and Thr686.

\section{Conclusion}

iGluRs are ligand-gated ion channels that play substantial role in development and function of the nervous system. Their involvement in numerous neudegenerative diseases, as well as in the process of learning and memory, has aroused widespread interest in their function and structure. Since the first publication of the crystal structure of a soluble construct of the GluA2-LBD, extensive studies were performed on GluA2 and the other iGluR subunits. Recently, a crystal structure of full-length GluA2 was determined, and it was proved that the soluble GluA2 LBD is a model system of the full-length receptor, as the dimeric unit is very similar. Structural studies on wild type and mutant GluA LBD construct in complex with agonists, partial agonists, antagonists, combined with functional data provide detailed understanding of these group of receptors, their activation, desensitation, inhibition and subunit selectivity. In this review we give one global picture of nowadays findings made on these receptors which are suitable base for future research as well as achievement in design of new selective drugs used for treatment of numerous neurodegenerative diseases.

\section{References}

Abele, R., Keinanen, K., Madden, D. R. 2000. Agonist induced isomerization in a glutamate receptor ligand-bindingdomain. A kinetic and mutagenetic analysis. J. Biol. Chem. 275, 21355-21363.

Ahmed, A.H.Wang, Q., Sondermann, H., Oswald, R.E. 2009a. Structure of the S1S2 glutamate binding domain of GLuR3. Proteins 75, 628-637.

Ahmed, A.H., Thompson, M.D., Fenwick, M.K., Romero, B., Loh, A.P., Jane, D.E., Sondermann, H., Oswald, R.E. 2009b. Mechanisms of antagonism of the GluR2 AMPA receptor: structure and dynamics of the complex of two willardine antagonists with the glutamate binding domain. Biochemistry 48, 3894-3903 
Arinaminpathy, Y., Sansom, M.S.P., Biggin, P.C. 2006. Binding site flexibility: molecular simulation of partial and fullagonists within a glutamate receptor. Mol. Pharmacol. $69,11-18$.

Armstron, N., Sun, Y., Guo-Qiang Chen,G.Q., Gouaux, E. 1998. Structure of a glutamate-receptor ligand-binding core in complexwith kainate. Nature 395, 913-917.

Armstrong, N., Gouaux, E.2000. Mechanisms for activation and antagonism of an AMPA-sensitive glutamate receptor: crystal structures of the GluR2 ligand binding core. Neuron $28,165-181$.

Ayalon, G., Stern-Bach, Y. 2001. Functional assembly of AMPA and kainate receptors is mediated by several discrete proteinprotein interactions. Neuron 31, 103-113.

Ayalon, G., Segev, E., Elgavish, S., Stern-Bach, Y. 2005. Two regions in the $\mathrm{N}$-terminal domain ofionotropic glutamate receptor 3 form the subunitoligomerization interfaces that control subtype-specific receptor assembly. J. Biol. Chem. $280,15053-15060$

Banke, T.G., Greenwood, J.R., Christensen, J.K., Liljefors,T., Traynelis, S.F., Schousboe, A., Pickering, D.S. 2001. Identification of amino acid residues in GluR1 responsible for ligand binding and desensitization. J. Neurosci. 21, 3052-3062.

Bowie, D. 2008. Ionotropic glutamate receptors and CNS disorders. CNS Neurol. Disord. Drug Targets 7, 129-143.

Brauner-Osborne, H., Egebjerg, J., Nielsen, E., Madsen, U., Krogsgaard-Larsen, P. 2000. Ligands for glutamate receptors: design and therapeutic prospects. J. Med. Chem. 43, 2609-2645.

Burnashev, N., Monyer, H., Seeburg, P.H., Sakmann, B. 1992. Divalent ion permeabilityof AMPA receptor channels is dominated by the edited form of a single subunit. Neuron 8, 189-198

Chen, G., Gouaux, E. 1997. Overexpression of a glutamate receptor (GluR2) ligandbinding domain in Escherichia coli: application of a novel protein folding screen. Proc. Natl. Acad. Sci. 94, 1331-1336.

Chen, E.P., Geballe, T.M., Stansfeld, J.P., Johnston, R.A., Yuan, H., Jacob, L.A., Snyder, P.J., Traynelis, S.F., Wyllie, A.J.D. 2005. Structural Features of the Glutamate Binding Site in Recombinant NR1/NR2A N-Methyl-d-aspartate Receptors Determined by Site-Directed Mutagenesis and Molecular Modeling. Molecular Pharmacology 67 (5) 1470-1484.

Clements, J.D., Felz, A., Sahara., Y., Westbrook, G.L. 1998. Activation kinetics of AMPA receptor channels reveal the number of functional agonist binding sites. J.Neurosci. 18, 119-127.

Collingridge, G.L., Olsen, R.W., Peters, J., Spedding, M.2009. A nomenclature for ligand-gated ion channels. Neuropharmacology 56, 2-5.

Coquelle, T.,Christensen, J. K., Banke, T. G., Madsen,U., Schousboe, A., Pickering, D. S.2000. Agonist discrimination between AMPA receptor subtypes. Neuroreport. 11, 2643-2648.

Dingledine, R., Borges, K., Bowie, D., Traynelis, S.F. 1999. The glutamate receptor ion channels. Pharmacol. Rev. 51, 7-61.

Foster, A.C., Fagg, G.E. 1984. Acidic amino acid binding sites in mammalian neuronal membranes: their characteristics and relationship to synaptic receptors. Brain Res. Rev. 7, 103164.

Foster, A.C., Kemp, J.A. 2006. Glutamate- and GABA-based CNS therapeutics. Curr.Opin.Pharmacol. 6-17.
Gouaux, E. 2004. Structure and function of AMPA receptors. J. Physiol. 554, 249-253.

Herin, G.A., Aizenman, E. 2004. Amino terminal domain regulation of NMDA receptor function. Eur. J. Pharmacol. 500, 101-111.

Hogner, A., Kastrup, J.S., Jin, R., Liljefors, T., Mayer, M.L., Egebjerg, J., Larsen, I.K., Gouaux, E. 2002. Structuralbasis for AMPA receptor activation and ligand selectivity: crystal structures of five agonist complexes with the GluR2 ligandbinding core. J. Mol. Biol. 322, 93-109.

Hogner, A., Greenwood, J.R., Liljefors, T., Lunn, M.L.,Egebjerg, J., Larsen, I.K., Gouaux, E., Kastrup, J.S.2003.Competitive antagonism of AMPA receptors by ligands of different classes: crystal structure of ATPO bound to the GluR2 ligand-binding core, in comparison with DNQX. J. Med. Chem. 46, 214-221.

Hollmann, M., Hartley, M., Heinemann, S. 1991. $\mathrm{Ca}^{2+}$ permeability of KA- AMPA - gated glutamate receptor channels depends on subunit composition. Science 252, 851-853.

Hume, R.., Dingledine, R., Heinemann, S.F. 1991. Identification of a site inglutamate receptor subunits that controls calcium permeability. Science 253, 1028-103.

Jin, R., Horning, M., Mayer, L.M., Gouaux, E. 2002. Mechanism of Activation and Selectivity in a Ligand-Gated Ion Channel: Structuraland Functional Studies of GluR2 and Quisqualate. J. Biochem. 41, 15653-15643.

Jin, R., Gouaux, E. 2003. Probing the function, conformational plasticity, and dimer-dimer contacts of the GluR2 ligand binding core: studies of 5-substituted willardiines and GluR2 S1S2 in the crystal. Biochemistry 42, 5201-5213.

Jin, R., Singh, S.K., Gu, S., Furukawa, H., Sobolevsky, A.I., Zhou, J., Jin, Y., Gouaux, E. 2009. Crystal structure and association behaviour of the GluR2 amino-terminal domain. EMBO J. 28, 1812-1823.

Kasper, C., Lunna, M.L., Liljefors, T., Gouaux. E., Egebjerg, J., Kastrupa, J.S. 2002. GluR2 ligand-binding core complexes: importance of the isoxazololmoiety and 5-substituent for the binding mode of AMPA-type agonists. FEBS 531, 173-178.

Kasper, C., Pickering, S.D., Mirza, O., Olsen, L., Kristensen, A.S., Greenwood, J. R., Liljefors, T., Schousboe, A., Wa"tjen, F., Gajhede, M., Sigurskjold, B.W., Kastrup, J.S. 2006. The Structure of a Mixed GluR2 Ligand-bindingCore Dimer in Complex with (S)-Glutamateand the Antagonist (S)-NS 1209. J. Mol. Biol. 357, 1184-1201.

Kasper, C., Frydenvang, K., Naur, P., Gajhede, M., Pickering, D.S., Kastrup, J.S. 2008. Molecular mechanism of agonist recognition by the ligand-binding core of the ionotropic glutamate receptor 4. FEBS Lett. 582, 4089-4094.

Köhler, M., Kornau, H.C., Seeburg, P.H. 1994.The organization of the gene for thefunctionally dominant $\alpha$-amino-3-hydroxy-5methyl-isoxazole-4-propionic acid receptorsubunit GluR-B. J.Biol.Chem. 269, 17367-7370.

Krogsgaard-Larsen, P., Honore, T., Hansen, J.J., Curtis, D.R., Lodge, D.1980. New class of glutamate agonist structurally related to ibotenic acid. Nature 284, 64-66.

Kuryatov, A., Laube, B., Betz, H., Kuhse, J. 1994. Mutational analysis of the glycinebindingsite of the NMDA receptor: Structural similarity with bacterial amino acidbindingproteins. Neuron 12, 1291-1300.

Laube, B.,Hirai, H., Sturgess, M., Betz, H., Kuhse, J. 1997. Molecular determinants ofagonist discrimination by NMDA receptor subunits: analysis of the glutamate binding site onthe NR2B subunit. Neuron 18, 493-503. 
Laube, B., Kuhse, J., Betz, H. 1998. Evidence for a tetrameric structure of recombinant NMDA receptors. J.Neurosci. 8, 2954-2961.

Lomeli, H., Mosbacher, J., Melcher, T., Höger, T., Geiger, J.R.P., Kuner, T., Monyer, H., Higuchi, M., Bach, A., Seeburg, P.H.1994. Control of kinetic properties of AMPA receptor channels by nuclear RNA editing. Science 266, 1709-1717.

Lunn, M.L., Hogner, A., Stensbol, T.B., Gouaux, E., Egebjerg, J., Kastrup, J.S. 2003. Three-dimensional structure of the ligand-binding core of GluR2 in complex with theagonist (S)-ATPA: implications for receptor subunit selectivity. J. Med. Chem., 46, 872-875.

Madsen, U., Pickering, D. S., Nielsen, B., Brauner-Osborne, H. 2005. 4-Alkylated homoibotenic acid (HIBO) analogues: versatile pharmacological agents with diverse selectivity profiles towards metabotropic and ionotropic glutamate receptor subtypes. Neuropharmacology 49 Suppl 1, 114119.

Mano, I., Teichberg, V.I. 1998.A tetrameric subunit stoichiometry for a glutamatereceptor-channel complex. Neuro Report 9, 327-331.

Mayer, M.L., Armstrong, N. 2004. Structure and function of glutamate receptor ion channels. Annu. Rev. Physiol. 66, 161-181.

Mayer, M.L. 2005a. Crystal structures of the GluR5 and GluR6 ligand binding cores: molecular mechanisms underlying kainate receptor selectivity. Neuron 45, 539-552.

Mayer, M.L.2005b.Glutamate receptor ion channels. Curr. Opin. Neurobiol. 15, 282-288.

McFeaters, R.L., Oswald, R.E. 2004. Emerging structural explanations of ionotropic glutamate receptor function. FASAB 18, 428-438.

Meldrum, B.S. 2000. Glutamate as a neurotransmitter in the brain: review of physiology and pathology. J. Nutr. 130, 1007-1015

Meucci, O., Miller, R.J.1998. Dissociation between the Joro spider toxin sensitivity of recombinant $\alpha$-amino-3-hydroxy5-methyl-4-isoxazole propionic acid receptors and their ability to increase intracellular calcium. Neuropharmacology 37, 1431-1443.

Nakanishi, S. 1992. Molecular diversity of glutamate receptor and implications for brainfunction. Science 258,597-602.

Naur, P., Vestergaard, B., Skov, L.K., Egebjerg, J., Gajhede, M., Kastrup, J.S. 2005. Crystal structure of the kainate receptor GluR5 ligand-binding core in complex with (S)-glutamate. FEBS Lett. 579, 1154-1160.

Nielsen, E.O., Varming, T., Mathiesen, C., Jensen, L. H., Møller, A., Gouliaev, A. 1999. SPD 502: awater-soluble and in vivo long-lasting AMPA antagonist with neuroprotective activity. J. Pharmacol. Expt.Ther. 289, 1492-1501.

Nielsen, B., Pickering, D. S., Greenwood, J. R.,Brehm, L., Gajhede, M., Schousboe, A., Kastrup, J. S. 2005. Exploring the GluR2 ligand-binding core in complex with the bicyclical AMPA analogue (S)-4-AHCP. FEBS J. 272, 1639-1648.

Olsen, R.W., Szamraj, O., Houser, C.R. 1987. [3H]AMPA binding to glutamate receptor subpopulation in rat brain. Brain Res. 402, 243-254.

Partin, K.M., Patneau, D.K., Mayer, M.L. 1994. Cyclothiazide differentially modulate desensitization of alpha-amino-3hydroxy-5-methyl-4-isoxazole propionic acid receptor splice variants. Mol.Pharmacol. 46, 129-138.

Partin, K.M., Bowie, D., Mayer, M.L. 1995. Structural determinants of allosteric regulation in alternatively spliced
AMPA receptors. Neuron 14, 833-843.

Patneau, D.K., Mayer, M.L., Jane, D.E., Watkins, J.C. 1992. Activation and desensitization of AMPA/kainate receptors by novel derivatives of willardiine. J. Neurosci. 12, 595606.

Perez-Otano, I., Ehlers, M.D. 2005. Homeostatic plasticity and NMDA receptor trafficking. Trends Neurosci. 28, 229-238.

Pøhlsgaard J., Frydenvang K., Madsen U., Kastrup J.S. 2011. Lessons from more than 80 structurres of GluA2 ligandbinding domain in complex with agonists, antagonists and allosteric modulators. Neuropharmacology 60, 135-150.

Rosenmund, C., Stern-Bach, Y., Stevens, C.F.1998. The tetrameric structure of aglutamate receptor channel. Science 280, 15961599.

Roche, K.W., O’Brien, R.J., Mammen, A.L., Bernhardt, J., Huganir R.L. 1996. Characterization of multiple phoshorylation sites on the AMPA receptor GluR1 subunit. Neuron 16, 11791188.

Schwarz, MK., Pawlak, V., Osten, P., Mack, V., Seeburg, P.H., Köhr, G. 2001. Dominance of the lurcher mutation in heteromeric kainate and AMPA receptor channels. Eur. J. Neurosci.14, 861-868.

Sekiguchi, M., Fleck, M.W., Mayer, M.L., Takeo, J., Chiba, Y., Yamashita, S., Wada, K.. 1997. A novel allosteric potentiator of AMPA receptors: 4-[2-(phenylsulfonylamino) ethylthio]2,6-difluoro-phenoxyacetamide. J. Neurosci. 17, 57605771 .

Sobolevsky, A.I., Rosconi, M.P., Gouaux, E. 2009. X-ray structure, symmetry and mechanism of an AMPA-subtype glutamate receptor. Nature 462, 745-756.

Spasenskiy, K., Kurnikova, M. 2005. On the binding determinants of the glutamate agonist with the glutamate receptor ligand binding domain. Biochemistry 44, 11508-11517.

Sprengel, R., Seeburg, P.H. 1993.The properties of glutamate receptor channels. FEBS Lett. 325, 90-94.

Stern-Bach, Y., Bettler, B., Hartley, M., Sheppard, P.O., O’Hara, P.J., Heinemann, S.F.1994. Agonist selectivity of glutamate receptors is specified by two domains structurally related to bacterial amino acid-binding proteins. Neuron 13, 13451357.

Sullivan, J.M., Traynelis, S.F., Chen, H-S.V., Escobar, W., Heinemann, S.F., Lipton, S.A. 1994. Identification of two cysteine residues that are required for redox modulation of the NMDA subtype of glutamate receptor. Neuron 13, 929936.

Sun, Y., Olson, R., Horning, M., Armstrong, N., Mayer, M., Gouaux, E. 2002. Mechanism of glutamate receptor desensitization. Nature 417, 245-253.

Sutcliffe, M.J., Wo, Z.G., Oswald R.E.,1996. Three-dimensional models of non-NMDA glutamate receptors. Biophys. J. 70, 1575-1589.

Taverna, F., Xiong, Z., Brandes, L., Roder, J.C., Salter, M.W., MacDonald, F.F. 2000. The lurher mutation of an $\alpha$-amino3-hydroxy-5-methyl-4-isoxazole propionic acid receptor subunit enhances potency of glutamate and converts antagonist to an agonits. J.Biol.Chem. 273, 8475-8479.

Vogensen, S.B. 2007. A tetrazolyl substituted subtype-selective AMPA receptor agonist. J. Med. Chem. 50, 2408-2414.

Washburn, M.S., Dingledine, R. 1996. Block of of $\alpha$-amino3-hydroxy-5-methylisoxazole-propionic acid (AMPA) receptors by polyamines and polyamine toxins. J.Pharmacol. Exp. Ther. 278, 669-678. 
Watkins, JC., Krogsgaard-Larsen, P.,Honor, T. 1990. Structureactivity relationships in the development of excitatory amino acid receptor agonists and competitive antagonists. Trends Pharmacol. Sci. 6, 25-33.
Wollmuth, L.P., Sobolevsky, A.I. 2004. Structure and gating of the glutamate receptor ion channel.Trends. Neurosci. 27, $321-328$

\title{
Резиме
}

\section{Јонотропно глутамински (iGluRs): Преглед на iGluR2 лиганд врзувачкиот домен во комплекс со агонисти и антагонисти}

\author{
Зорица Серафимоска ${ }^{1 *}$, Томи Н. Јохансен ${ }^{2}$, Карла Фриденванг ${ }^{2}$, \\ Љубица Шутуркова ${ }^{1}$
}

\author{
${ }^{1}$ Институт за фармацевтска хемија, Фармацевтски факултет, Универзитет “Св. Кирил и Методиј” Скопје, \\ Македонија \\ ${ }^{2}$ Институт за медицинска хемија, Факултет за фармацевтски науки, Универзитет Копенхаген, Данска
}

Клучни зборови: Јонотропни глутамински рецептори (iGluRs), AMPA(iGluA1-4), невролошки пореметувања, невродегенеративни заболувања, шизофренија, Алцхајмерова болест, епилепсија.

Јонотропните глутамински рецептори (iGluRs) претставуваат фамилија на лиганд врзувачки јонски канали поделени во три класи, NMDA, AMPA(iGluA1-4) и KA (1-5). Оваа поделба е направена во зависност од агонистот кој врши нивна селективна активација. iGluRs се тетрамерни групации од високо хомологни рецепторни подединици. Овие рецептори се од круцијално значење за нормалната функција на мозокот и се смета дека тие се вклучени во бројни невролошки пореметувања и невродегенеративни заболувања како шизофренија, Алцхајмерова болест, епилепсија и оштетувања на мозокот кои настануваат после мозочен удар. По објавувањето на структурата на првиот рекомбинантен растворлив протеин на лиганд врзувачкиот домен од GluA2 рецепторот спроведени се бројни студии врз оваа група на рецептори и добиени се многу кристални структури од комплексите на GluA2-LBD со агонисти, парцијални агонисти и антагонисти. Податоците добиени од структурните анализи во комбинација со функционалните податоци даваат добра основа за понатамошно испитување и дизајнирање на нови селективни лекови кои ќе бидат користени во третманот на невродегенеративните заболувања. 